\title{
Combined application of Ascophyllum nodosum extract and chitosan synergistically activates host-defense of peas against powdery mildew
}

Jai Singh Patel, Vinodkumar Selvaraj, Lokanadha Rao Gunupuru, Pramod Kumar Rathor and Balakrishnan Prithiviraj “ (D)

\begin{abstract}
Background: Powdery mildew (PM) is an important disease of pea that reduce yield. Ascophyllum nodosum extract (ANE) and chitosan (CHT) are biostimulants used to improve plant health. Efficacy of ANE and CHT was assessed individually and in combination against pea powdery mildew.

Results: Combined applications of ANE and CHT had a significant inhibitory effect on pathogen development and it reduced disease severity to 35\%, as compared to control (90.5\%). The combination of ANE and CHT enhanced the activity of plant defense enzymes; phenylalanine ammonia lyases (PAL), peroxidase (PO) and production of reactive oxygen species (ROS) and hydrogen peroxide $\left(\mathrm{H}_{2} \mathrm{O}_{2}\right)$. Further, the treatment increased the expression of a number of plant defense genes in jasmonic acid (JA) signaling pathway such as LOX1 and COI and salicylic acid (SA)mediated signaling pathway such as NPR1 and PR1. Other genes involved in defense mechanisms like NADPH oxidase and $\mathrm{C} 4 \mathrm{H}$ were also upregulated by the combination treatment.
\end{abstract}

Conclusion: The combination of ANE and CHT suppresses pea powdery mildew largely by modulating JA and SAmediated signaling pathways.

Keywords: Plant-microbe interaction, Seaweed extract, Plant immunity, Sustainable agriculture

\section{Background}

Powdery mildew (PM) of pea (Pisum sativum L.) is caused by an obligate, parasitic fungus Erysiphe pisi. Powdery mildew infects all above-ground parts of pea plant, which causes significant negative effects on productivity, including a reduction in the number of pods and seeds [1] The disease was reported to cause $25-50 \%$ yield loss [2, 3]. Erisyphe pisi propagates through the production of ascospores and conidia [4]. Both conidia and ascospores germinate on pea plant, develop appressoria on the surface and infect epidermis $[5,6]$.

Indiscriminate use of pesticides has resulted in the development of resistance in a number of common pathogens, as well as losses of beneficial microflora and fauna. Furthermore, there is an increasing demand for pesticide-free food

\footnotetext{
* Correspondence: bprithiviraj@dal.ca

Department of Plant Food and Environmental Sciences, Dalhousie University, Nova Scotia, Canada
}

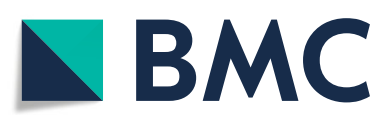

(c) The Author(s). 2020 Open Access This article is distributed under the terms of the Creative Commons Attribution 4.0 International License (http://creativecommons.org/licenses/by/4.0/), which permits unrestricted use, distribution, and reproduction in any medium, provided you give appropriate credit to the original author(s) and the source, provide a link to the Creative Commons license, and indicate if changes were made. The Creative Commons Public Domain Dedication waiver (http://creativecommons.org/publicdomain/zero/1.0/) applies to the data made available in this article, unless otherwise stated. amongst discerning consumers which requires the development of eco-friendly plant protection practices. The use of seaweed-derived products in agriculture has been steadily increasing in the recent years. Ascophyllum nodosum is an intertidal, brown alga found around the north Atlantic Ocean and the northwestern coast of Europe [7]. A. nodosum biomass is used to produce one of the most commonly studied seaweed-based biostimulants [8-10]. Commercial extracts of the brown alga have been reported to enhance plant growth as well as to promote the growth of beneficial soil microbes and induce plant resistance against biotic and abiotic stresses [9, 11]. Ascophyllum nodosum extracts (ANE) have been reported to suppress disease incidence and the growth of various pathogens including Alternaria cucumerinum, Didymella applanata, Fusarium oxysporum, Botrytis cinerea [12, 13], Colletorichum lagenarium [14], Phytophthora capsica [15] and Verticillium sp. [16]. The macro- and micronutrients, as well as the phyco-elicitors 
(compounds similar to plant hormones such as cytokinins, auxins and abscisic acid (ABA)-like substances) that are present in the macroalgal extracts were reported to have a beneficial effect on plant cellular metabolism, leading to enhanced crop growth and yield [17, 18]. Biologically active auxin-like compounds, and indole acetic acid (IAA), have also been reported in the alkaline hydrolysates of $A$. nodosum. In addition to these compounds, $A$. nodosum extracts also contains unique polysaccharides such as laminarin, fucoidan, and alginic acids $[9,19]$. Chitosan $(\mathrm{CHT})$ is a naturally occurring biopolymer (a derivative of chitin) that was shown to elicit plant defense mechanisms against a number of pathogens $[20,21]$. Chitosan treatment increased the synthesis of pathogenesis-related (PR) proteins, proteinase inhibitors, phytoalexins as well as callus formation and lignin synthesis. Root injection of chitosan in date palm (Phoenix dactylifera L.) elicited polyphenol oxidase (PPO) and peroxidase (PO) activities, resulting in increased levels of phenolic compounds [22]. Several other studies reported the use of chitosan against plant pathogens such as Erysiphe sp. and Blumeria graminis f. sp. hordei [23-25].

Several studies have shown ANE and CHT trigger plant defense responses by inducing the expression PAL, PO and $\mathrm{H}_{2} \mathrm{O}_{2}$. Foliar spray of ANE elicited activity of defenserelated enzymes, including peroxidase (PO), polyphenol oxidase (PPO), phenylalanine ammonia lyase (PAL) and chitinase in carrot [12] and cucumber [13]. Application of ANE on pepper plants resulted in multifold increases in peroxidase activity and phytoalexin synthesis [15]. Incorporation of ANE to planting medium resulted in the accumulation of higher concentration phenolics in pepper [16]. Similar results were reported with chitosan application. Spray treatment of okra plants with chitosan increased the total phenolic content and increased polyphenol oxidase, peroxidase, chitinase, and $\beta$-1,3-glucanase [26].

Earlier reports suggest ANE and CHT protect plant against pathogen by eliciting systemic resistance. ANE applications induced systemic resistance, largely through the jasmonic acid-dependent pathway [27]. In contrast, chitosan application elicited systemic acquired resistance, which is a salicylic acid mediated pathway [28]. This study focused on the effect of combined application of ANE and CHT on the development of PM, and possible mechanism(s) of action that leads to increased resistance against PM in pea.

\section{Results}

ANE and $\mathrm{CHT}$ reduce powdery mildew disease severity in pea

Pea seedlings (21 days post-planting) sprayed with ANE and $\mathrm{CHT}$ either alone or in combination exhibited enhanced resistance to the powdery mildew. Disease severity in all treatments was significantly $(P \leq 0.05)$ lower

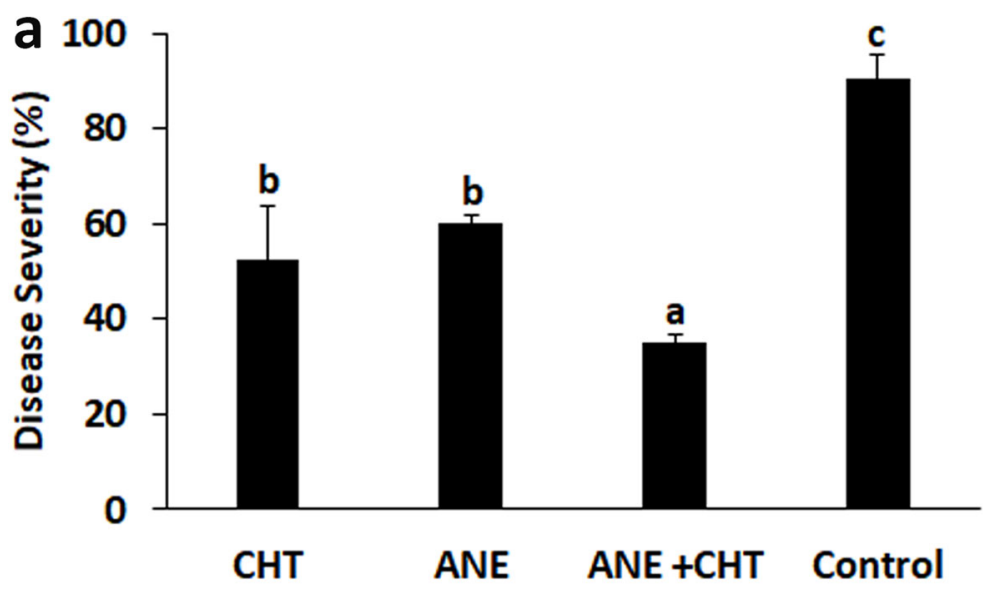

b

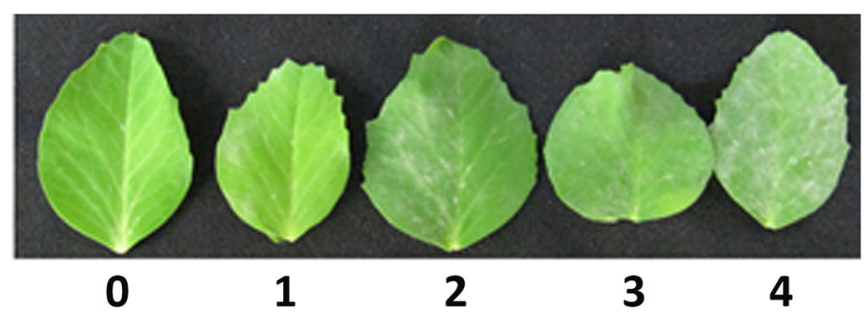

Fig. 1 Suppression of powdery mildew by Ascophyllum nodosum extract and chitosan. (CHT=Chitosan 100 ppm, ANE =A. nodosum Extract $0.015 \%)$. The data was recorded 15 days after pathogen inoculation. 10 replicates with 12 plants in each replicate were used in the experiment. Error bars represent SD (Standard Deviation). Bars with different letters are significantly different ( $P \leq 0.05$; Duncan's multiple range test) 
compared to the control (sprayed with sterilized distilled water). The percent disease incidence (PDI)) in treatments were $35 \%$ in $\mathrm{ANE}+\mathrm{CHT}, 60 \%$ in $\mathrm{ANE}$, and $52.5 \%$ in CHT- $52.5 \%$, as compared to $90.5 \%$ in the control (Fig. 1). The combined application also inhibited pathogen establishment by supressing the development of germ tubes to 0.45 /spore, appressoria to 0.2 /spore and germ tube length to $0.046 \mathrm{~mm}$, compared to the control (Figs. 2 and 3). Moreover, browning of the plant cells adjacent to the germinating spores was also observed (Fig. 4). This indicated a hypersensitive response, triggered by the pathogen challenge, in CHT and ANE + CHT treatments.

\section{ANE and CHT synergistically induce plant defense responses}

ANE and CHT both when applied alone or in combination induced plant defense related enzymes like phenyl alanine ammonia lyase (PAL) and peroxidase and as well as increased the concentration of total phenolics. The phenyl alanine ammonia lyase (PAL) activity increased gradually $24 \mathrm{~h}$ after treatment and was the highest at $72 \mathrm{~h}$ post treatment. Plants treated with ANE $+\mathrm{CHT}$ exhibited the highest PAL activity $(1.369 \mathrm{nmol}$ cinnamic acid $/ \mathrm{min} /$ mg protein), followed by the ANE alone $(1.14 \mathrm{nmol}$ cinnamic acid $/ \mathrm{min} / \mathrm{mg}$ protein) while CHT alone $(0.90 \mathrm{nmol}$ cinnamic acid/min/mg protein) had a higher PAL activity as compared to the control, and all treatments were statistically significant at $P \leq 0.05$ (Fig. 5a). Peroxidase activity gradually increased after $24 \mathrm{~h}$, and at $0.70 \mathrm{Unit} / \mathrm{min} / \mathrm{g}$ fresh weight $(\mathrm{FW})$ was the highest in the ANE + CHT treatment after $48 \mathrm{~h}$. After $72 \mathrm{~h}$ of pathogen challenge, $\mathrm{PO}$ activity dropped in the combined treatment to $0.01 \mathrm{U} /$ $\mathrm{min} / \mathrm{g} \mathrm{FW}$. The ANE + CHT treatment therefore outperformed all other treatments. Interestingly, PAL activity in plants treated with $\mathrm{ANE}+\mathrm{CHT}$ was stable, did not vary over time (Fig. 5b). The highest $\mathrm{H}_{2} \mathrm{O}_{2}$ production $(75.73 \mu \mathrm{g} / \mathrm{g}$ of $\mathrm{FW})$ was observed in $\mathrm{ANE}+\mathrm{CHT}, 48 \mathrm{~h}$

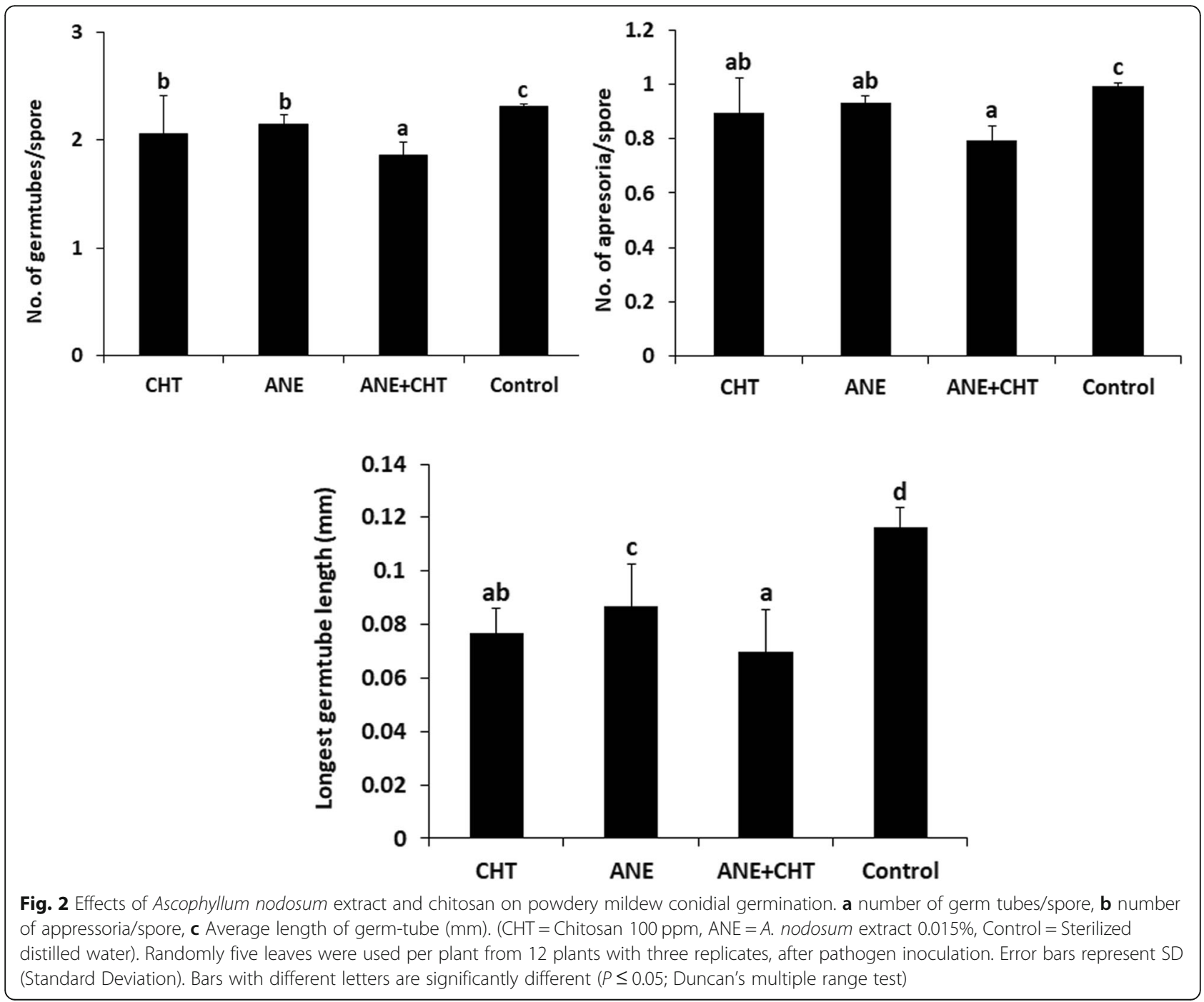




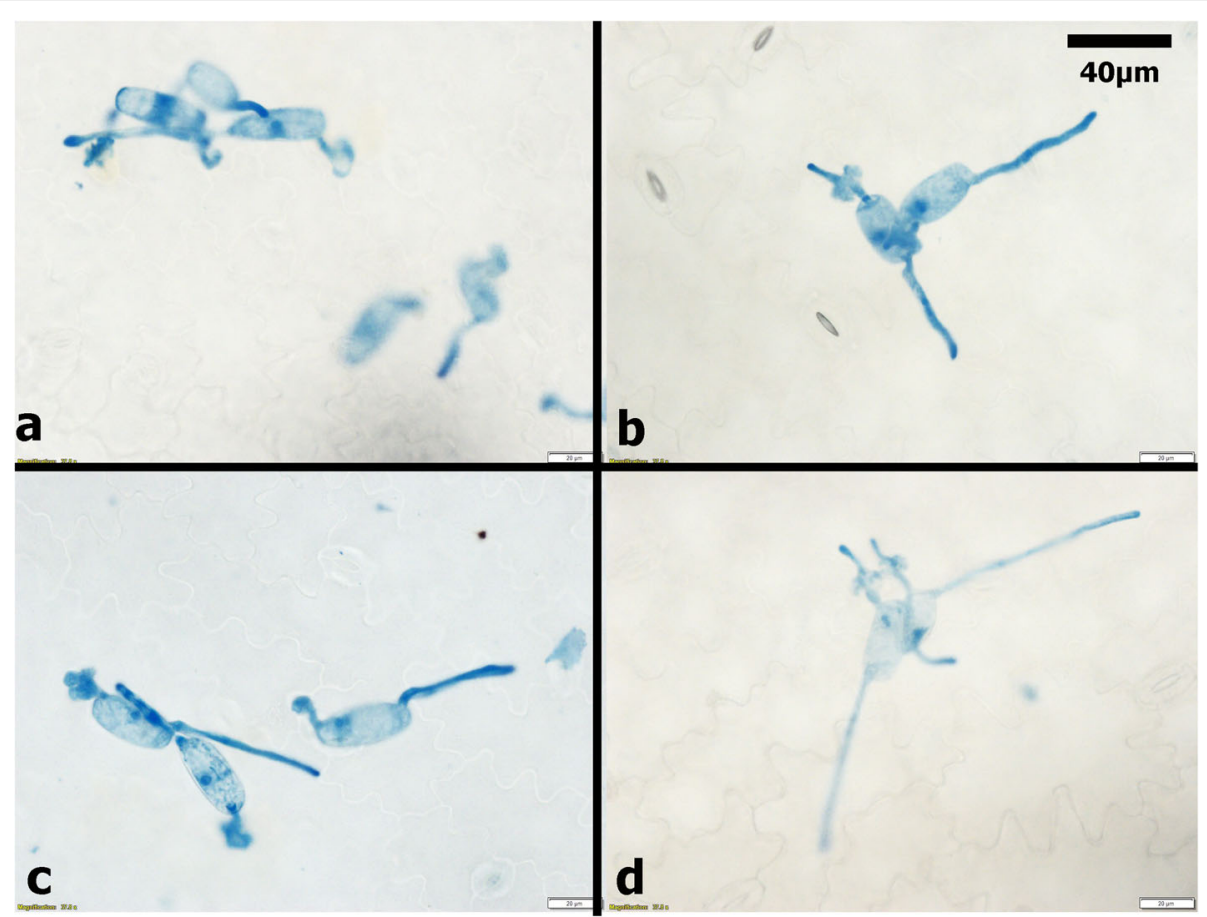

Fig. 3 Ascophyllum nodosum extract and chitosan inhibited conidial germination of powdery mildew. a CHT (chitosan 100 ppm) b ANE (A. nodosum extract $0.015 \%$ ) c ANE + CHT $\mathbf{d}$ Control (sterile distilled water)

after the treatment, and the activity decreased sharply at $72 \mathrm{~h}$. The $\mathrm{H}_{2} \mathrm{O}_{2}$ concentration in CHT $(47.7 \mu \mathrm{g} / \mathrm{g}$ of FW) and ANE $(42.21 \mu \mathrm{g} / \mathrm{g}$ of FW) treated plants were similar (Fig. 5c). Concentration of total Phenolics in pea plants treated with the combination treatment were $8.89,19.18$ and $18.38 \mu \mathrm{g} / \mathrm{g}$ of FW 24,48 and $72 \mathrm{~h}$, respectively and was significantly higher $(P \leq 0.05)$, as compared with all other treatments (Fig. 5d). Notably, the accumulation of TPC in plants from the ANE + CHT treatment was stable and did not decline significantly at $72 \mathrm{~h}$.

\section{ANE and CHT enhanced the accumulation of transcripts involved in defense response mechanisms}

Pea plants treated with ANE + CHT had the highest transcript abundance of defense response genes (Fig. 6). NPR1 and $P R 1$ gene transcripts were relatively higher, 10.41 fold and 2.57 fold increases respectively, as compared to the un-treated control. This indicated the activation of SAmediated signalling. Similarly, the combined treatment also increased transcripts of JA-mediated signalling genes, LOX (11.09 fold), COI (2.96 fold) and PDF1.2 (2.38 fold) as well as cinnamic acid-4-hydroxylase $(\mathrm{C} 4 \mathrm{H})$ (3.72 fold) gene.

\section{Discussion}

In the present study, the combined treatment of ANE + $\mathrm{CHT}$ outperformed other treatments (ANE or CHT alone) in suppressing powdery mildew through the induction of defense mechanisms in pea plant. Commercial extracts of $A$. nodosum have been reported to be efficient in mitigating several biotic and abiotic stresses in plants. ANE also promote plant growth while polysaccharides and oligosaccharides present in the extract are potent elicitors (phyco-elicitors) of plant defense responses [29].

Anti-fungal activity of ANE have been well documented against various plant pathogens [13]. Similarly, the anti-fungal activity of chitosan was reported [10]. Foliar spray of chitosan reduced powdery mildew in plants such as okra [26] barley [23] and grapevine [25]. Moreover, chitosan exhibited direct anti-fungal activity inhibiting spore germination of a number of plant pathogens. Chitin oligosaccharides inhibited spore germination and resulted in pore-formation and cellular leakage in the growing hyphae of Fusarium sp. [30]. Mycelial growth and spore germination of Colletotrichum gloeosporioides was also inhibited by chitosan. In addition, the treatment resulted in structural degradation of the hyphae [31]. However, the efficacy of the combined effect of ANE and CHT on PM infection have not been reported. In present study the combined application of two biostimulants resulted in a better disease suppression as compared to individual treatments. Furthermore, the combined treatment reduced the number of germ tubes/conidia, the number of appressoria/conidia and germ-tube length. 


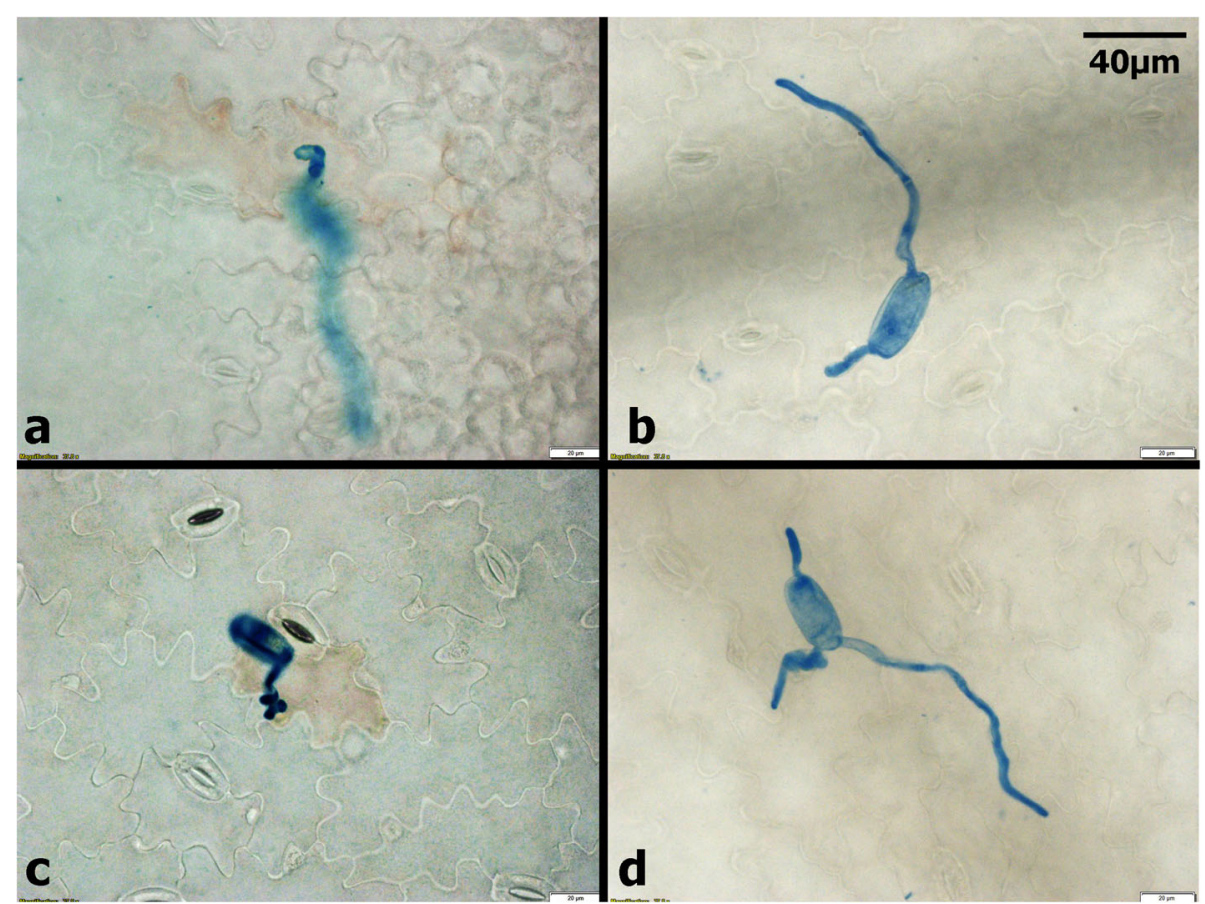

Fig. 4 Ascophyllum nodosum extract and chitosan induced hypersensitive response against powdery mildew pathogen. a CHT (chitosan 100 ppm) b ANE (A. nodosum extract 0.015\%) c ANE + CHT d Control (sterile distilled water)

A. nodosum extract-treatment increased transcripts of pathogenesis-related protein I (PR-I), lipid transfer protein $(L T P)$, phenylalanine ammonia lyases $(P A L), N P R-I, P R-5$, WRKY30, and CYP71A12 [12, 13]. Previous reports showed that ANE treatment induced resistance in Arabidopsis mutants, deficient in salicylic acid (NahG and ics1), and they failed to do so in jar1 mutants. These results indicated that ANE activates the JA-dependent defense mechanism in plants [27]. Chitosan application induced the expression of PR protein such as chitinase and chitosanase, enzymes involved in the degradation of the cell wall of pathogens [32]. CHT applications induced key genes in both jasmonic acid [33] and salicylic acid [34] signaling pathways. Applications of CHT in rice plants induced key components of the octa-decanoic pathway such as 12-oxo-phytodienoic acid (OPDA) and jasmonic acid [35]. Other studies reported increased production of jasmonic acid (JA) upon CHT treatment in plants such as tomato [36], rice [35] and rape seed [37]. In contrast, a few studies reported increased production of salicylic acid (SA) $[28,38]$. The interaction between JA and SA defense pathway is complex and is likely to have evolved to fine-tune defense against continuously changing pathogen pressure. Both positive and negative interactions between the JA and SA mechanisms have been suggested. However, most of the interaction seem to be antagonistic in nature, where one suppresses the expression of the other. JA-dependent PR proteins including plant defensin 1.2 (PDF1.2), thionin2.1
(THI2.1), hevein like protein (HEL), and chitinaseB (CHIB) are commonly used to monitor JA-dependent defense responses [39]. NPR1 is a central regulator of plant defense responses and connects both SAR (Systemic Acquired Resistance) and ISR (Induced Systemic Resistance) [40, 41]. Furthermore, this gene has been reported for effectiveness against a large variety of organisms in SAR response [42].

The combined applications of ANE and CHT, resulted in the higher expression of of SA-mediated NPR1, PR1, as well as that of the JA-mediated LOX, COI and PDF1.2 genes. These observations suggest the possibility of SA and JA mediated signal resulting in suppression of PM infection. In this study, $\mathrm{H}_{2} \mathrm{O}_{2}$ production was significantly $(P \leq 0.05)$ higher in ANE $+\mathrm{CHT}$ treatment. The increase in transcripts of NADPH-oxidase may be correlated with ROS production [43]. Browning of host cells around the germinating conidia ot the site of PM infection indicated the possibility of hypersensitive response in plants treated with ANE + CHT. Further study using genomics, metabolomics or protemics approaches will contribute to the characterization of the mode of action of combination of ANE and CHT.

\section{Conclusion}

The combined application of ANE and CHT exhibited higher anti-fungal activity as compared to individual treatment. The components triggered the production of plant defense-related enzymes and metabolites. Furthermore, 


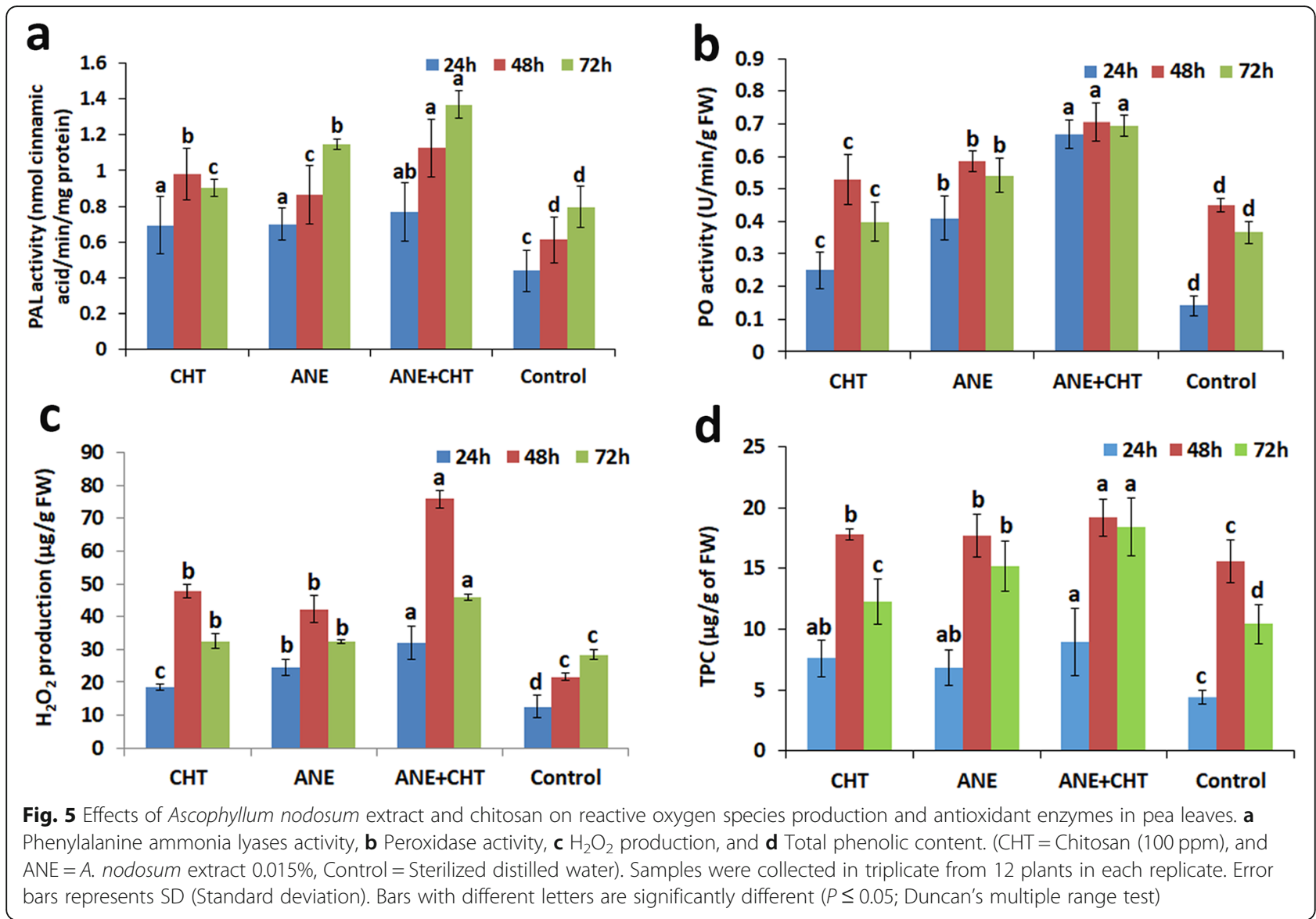

the combined treatment also induced transcripts of the SA and JA-dependent plant defense genes, which resulted in reduction of powdery mildew infection.

\section{Methods}

\section{Preparation of pea plants and pathogen inoculum}

Pea plant (cv. Sabre, Veseys Seed Canada) was grown in pots containing Promix ${ }^{\circ}$ (Premier Tech, QC, Canada). Plants were grown in greenhouse maintianed at 16:8 h light:dark cycle, at $21 \pm 2{ }^{\circ} \mathrm{C}$. Pathogen inoculum was collected from naturally infected pea plants in the field (Chef's Garden, Dalhousie University, Truro, Canada). The pathogen was identified by morphological characterization.

\section{Treatments and inoculation of pathogen}

Pea plants were spray treated with ANE - 0.015\% (Acadian Seaplants Limited, chemical composition of ANE was reported earlier [44]) and chitosan (CHT) - 100 ppm (Sigma Aldrich $^{\circ}$ ), individually and in combination. Plant was sprayed until drip. Control plants were sprayed with sterile distilled water. Treated plant was inoculated with Erysiphe pisi after $48 \mathrm{~h}$ following protocol described previoulsy [45]. The experiment was repeated three times with 10 replicates per treatments and 12 plants per replicate.
Efficiency of ANE and CHT in the suppression of PM disease development

Leaf samples were collected at $24 \mathrm{~h}$ and $48 \mathrm{~h}$ postinoculation to assess the efficiency of the treatment on conidial germination. The leaf was de-chlorophyllized with ethanol:acetic acid solution (3:1). The leaves were stained with lactophenol cotton blue (Merck, Germany). The number of germ-tubes/conidia, germ-tube length, number of appressoria/conidia were observed. Fifty spores were counted inr each treatment and mean value was obtained. Disease severity was observed 15 days, post inoculation, following $0-4$ scale [46], where $0=$ no visible sign of infection, $1=25 \%$ leaf area infected, $2=50 \%$ leaf area infected, $3=$ $75 \%$ leaf area infected and $4=100 \%$ leaf are infected with freely sporulating colonies (Fig. $3 \mathrm{~b}$ ). The percent disease index (PDI) was calculated following formula given below.

PDI $=\frac{\text { Sum of ratings }(0-4) \times 100}{\text { Maximum possible score } \mathrm{x} \text { Total no.of leaves examined }}$

Effect of ANE and CHT on induction of plant defense response Leaf samples were collected from PM-inoculated plants at $24 \mathrm{~h}, 48 \mathrm{~h}$ and $72 \mathrm{~h}$ post inoculation. Each treatment 

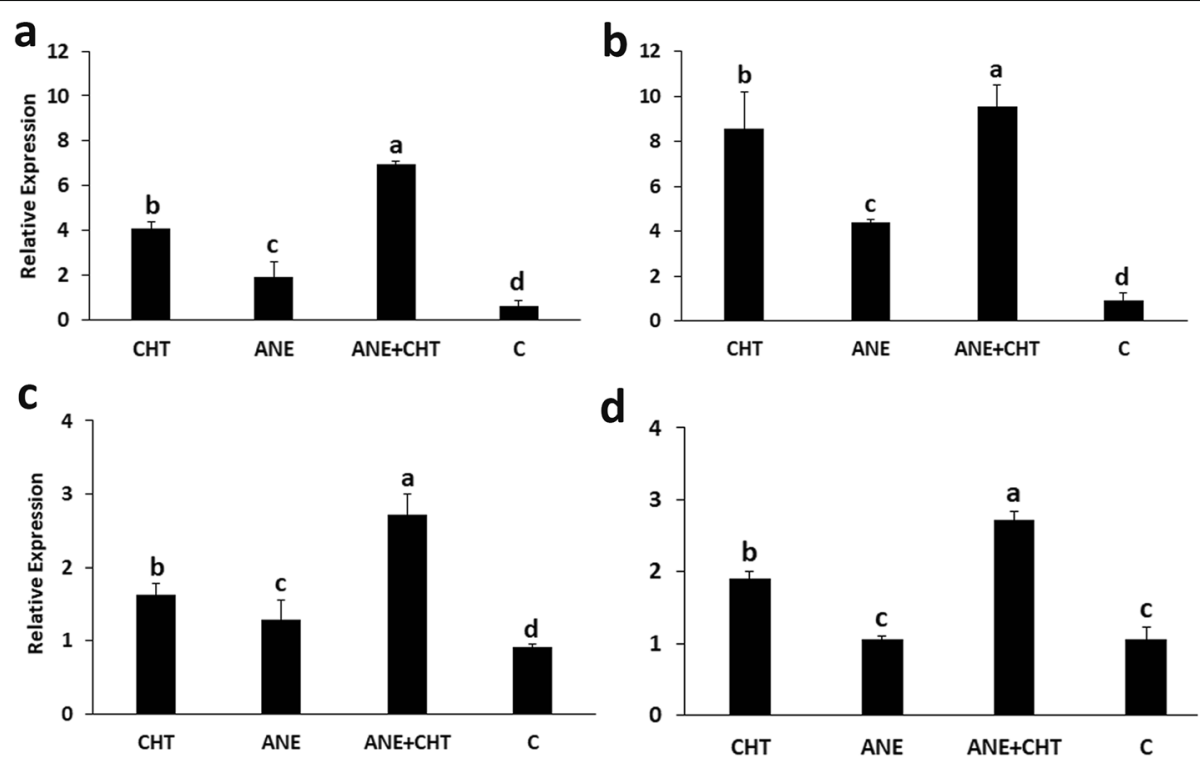

d
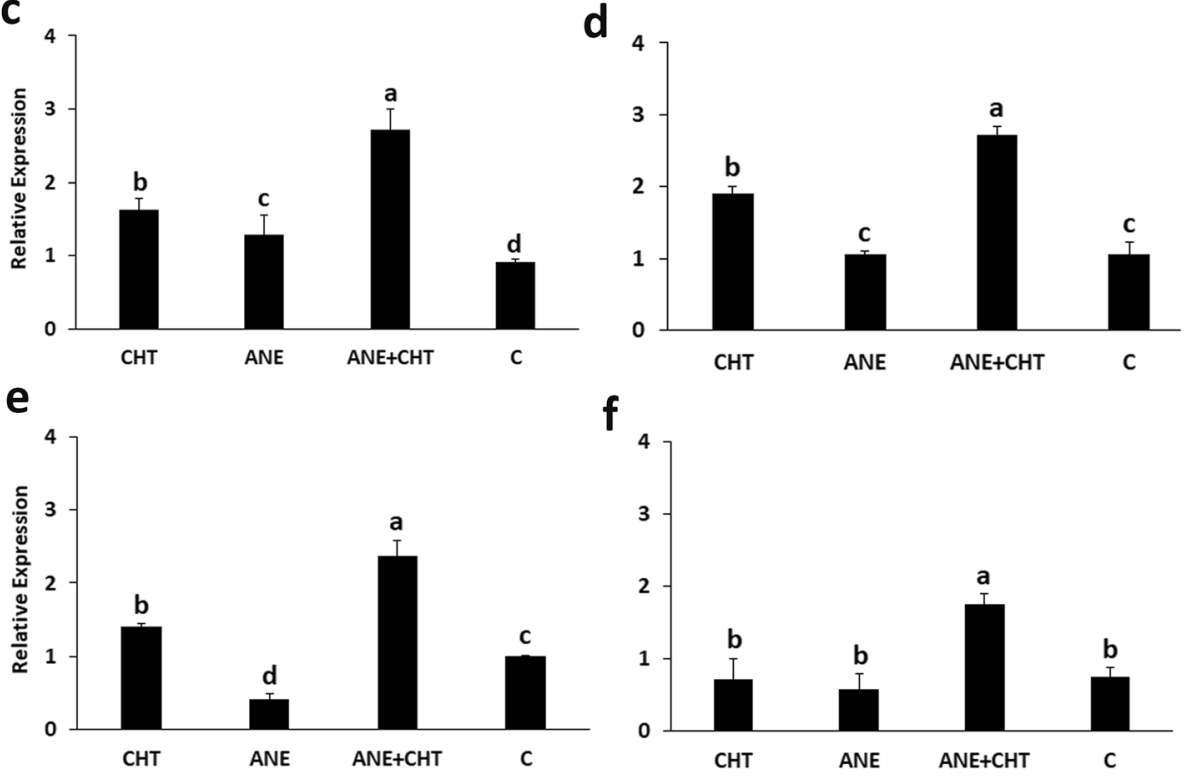

f

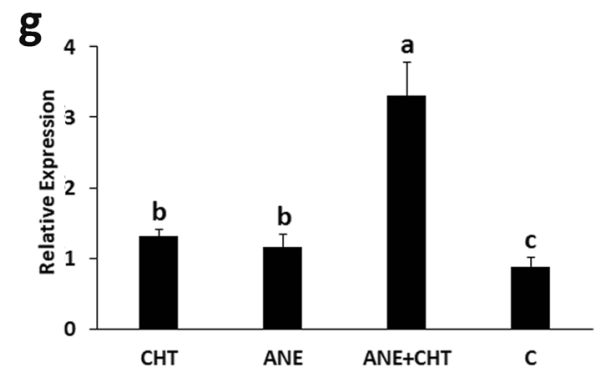

Fig. 6 Effect of Ascophyllum nodosum extract and chitosan on the transcription of defense response genes a NPR1, b COI, c LOX, d PR1, e PDF1.2, f NADPH Oxidase, and $\mathbf{g} C 4 \mathrm{H}$. (CHT = Chitosan $100 \mathrm{ppm}$, and ANE = Ascophyllum nodosum Extract $0.015 \%$, Control = Sterilized distilled water). Triplicate leaf tissue samples from 12 plants in each replicate were used in the experiment. Bars with different letters are significantly different ( $P \leq 0.05$; Duncan's multiple range test)

had 12 plants per replicate and the experiment was repeated twice.

\section{Phenylalanine ammonia lyases (PAL)}

Leaf sample $(0.5 \mathrm{~g}$ per treatment) was ground in $4 \mathrm{~mL}$ borate buffer $\left(\mathrm{pH} 8.7 ; 4^{\circ} \mathrm{C}\right)$ and centrifuged at 13,000 $\mathrm{rpm}$ for $15 \mathrm{~min}$ at $4{ }^{\circ} \mathrm{C}$. The supernatant was used as the enzyme source in the reaction mixture. The reaction mixture containing $0.2 \mathrm{~mL}$ enzyme extract, $1.3 \mathrm{~mL}$ distilled water and $1.0 \mathrm{~mL}$ phenylalanine $(0.1 \mathrm{M})$ was incubated at $32{ }^{\circ} \mathrm{C}$ for $30-60 \mathrm{~min}$ and the reaction was stopped by addition of $0.5 \mathrm{~mL}$ of $1 \mathrm{M}$ trichloroacetic acid. PAL activity was measured following the formation of trans-cinnamic acid at $290 \mathrm{~nm}$ as described [47] and expressed in terms of nmol trans-cinnamic acid per minute per milligram of fresh weight $(\mathrm{FW})$.

\section{Peroxidase (PO)}

The peroxidase (PO) assay was performed following published protocol [48]. Leaf tissue $(1 \mathrm{~g})$ was extracted in $4 \mathrm{~mL} 0.1 \mathrm{M}$ phosphate buffer ( $\mathrm{pH} 7.0$ ). The supernatant was used as the enzyme source and the reaction 
Table 1 List of Primers used in the experiment

\begin{tabular}{|c|c|c|c|}
\hline S.N. & Name of Gene & Forward primer 5'-3" & Reverse primer 5'-3' \\
\hline 1. & PR1 & 5'-TCTGAAGTTGGTGTTGGCCCT-3' & 5'-CCGAACCGAATTGCGCCAAA-3' \\
\hline 2. & PDF 1.2 & 5'-GCTGCCTTGTCCTTCCTCCTCC-3' & 5'-AGTGCGCTITGTTCTTGCAGTG-3' \\
\hline 3. & LOX2 & 5'-CTGGCCAAAGCTTATGTGGTCGT-3' & 5'-TCTCAACGGAATGCTTTGAGGGC-3' \\
\hline 4. & Ubiquitin & 5'-CGTTTGAGGGGAGGTATGCAAAT-3' & 5'-GTCCTACCATCCTCCAATTGCTTC-3' \\
\hline 5. & NPR1 & 5'- CTGAGAGAAGGGAGCCTTTACATGG -3' & 5'- ACTGCTCTAGACAATGCCTTCATCC - 3' \\
\hline 6. & $\mathrm{C} 4 \mathrm{H}$ & 5'- TAACCGCCATCACAATCTCA-3' & 5'- CTCGACTCCTTGGGTATGGA-3' \\
\hline 7. & NADPH oxidase & 5'- GGAGGAGCTTGGACACAGAAGC-3' & 5'- TCCACTTCCTCCACTCACCATCA-3' \\
\hline 8. & $\mathrm{COI}$ & 5'-CGGAGAAACAGATGCAGGGCT-3' & 5'-TCTTGGTCCAGCGAGGGAGT-'3 \\
\hline
\end{tabular}

mixture consisted of; $0.1 \mathrm{~mL}$ enzyme extract, $2.8 \mathrm{~mL}$ of $0.1 \mathrm{M}$ phosphate buffer ( $\mathrm{pH} 7.0$ ), $0.05 \mathrm{~mL}$ of $0.018 \mathrm{M}$ guaiacol and $100 \mu \mathrm{L}$ of $1 \% \mathrm{H}_{2} \mathrm{O}_{2}$. Absorbance of the reaction mixture were recorded using a spectrophotometer (Cytation 5 - BioTek, USA) $(\lambda=420 \mathrm{~nm})$ every $30 \mathrm{~s}$ for 3 minutes (6 absorbance values per reaction mixture). Enzyme activity was expressed as the change in OD per minute per gram of FW.

\section{Hydrogen peroxide $\left(\mathrm{H}_{2} \mathrm{O}_{2}\right)$}

For quantification of $\mathrm{H}_{2} \mathrm{O}_{2}, 0.1 \mathrm{~g}$ leaf sample was ground in $2.0 \mathrm{~mL}$ of $0.1 \%(\mathrm{w} / \mathrm{v})$ trichloroacetic acid in an ice bath. The extract was centrifuged at $12,000 \mathrm{~g}$ for $10 \mathrm{~min}$. The reaction mixture contained $0.5 \mathrm{~mL}$ of the supernatant, $10 \mathrm{mM}$ potassium phosphate buffer ( $\mathrm{pH}$ 7.0) and $1 \mathrm{~mL}$ of $1 \mathrm{M}$ potassium iodide. The mixture was incubated at room temperature for $5 \mathrm{~min}$ and absorbance measured using a spectrophotometer (Cytation 5 - BioTek, USA) $(\lambda=390 \mathrm{~nm})$ [49]. The amount of $\mathrm{H}_{2} \mathrm{O}_{2}$ was determined by comparing the results with a standard curve made with known concentrations of $\mathrm{H}_{2} \mathrm{O}_{2}$ and expressed in terms of $\mathrm{nmol} \mathrm{H}_{2} \mathrm{O}_{2} \mathrm{~g}^{-1}$ fresh weight (FW).

\section{Total phenolic content (TPC)}

Total phenolic content (TPC) was quantified following the method described previously [50]. Leaf tissue (1 g) was extracted in 50\% methanol. The supernatant was evaporated, dissolved in distilled water $(1 \mathrm{~mL})$ and analyzed with a spectrophotometer following the FolinCiocalteau method [51]. TPC was calculated in terms of gallic acid equivalents using a gallic acid standard curve.

\section{Effects of ANE and CHT on the defense related genes}

The relative expression of NPR1, LOX1, PDF1.2, NADPH Oxidase, $C 4 H$, and $P R 1$ were determined using quantitative real-time PCR (qRT-PCR). Total RNA was extracted from $200 \mathrm{mg}$ powdered leaf tissue using RNeasy plant mini-kit (QIAGEN) following the manufacturer's protocol. Three leaf samples were collected from each of the 12 replicate plants and pooled together to obtain total
RNA. The quantity and quality of the total RNA was assessed with a NanoDrop ${ }^{\mathrm{TM}} 2000$ spectrophotometer (ThermoScientific) and agarose gel electrophoresis. cDNA was synthesized using RevertAid RT Reverse Transcription Kit (ThermoScientific) following the manufacturer's protocol qPCR was carried out using StepOne ${ }^{\mathrm{Tm}}$ real-time PCR System (Applied Biosystem, USA) using SYBR ${ }^{\oplus}$ Green Supermix Kit (Bio-Rad, USA). Genespecific primers were designed using Primer3 software (Version 4.1.0) [52] and listed in Table 1. qRT-PCR assays were carried out by the following conditions mentioned in [53]. $2^{-\Delta \Delta C T}$ method was used to compare the fold change as described by [54]. The experiment was repeated thrice with three biological and three technical replicates.

\section{Statistical analysis}

Statistical analyses were completed using SPSS (Version 24). Experiments were repeated three times using a completely randomized design. Data are expressed as mean of three independent replications \pm standard deviation. Treatment means were separated by Duncan's multiple range test $(P \leq 0.05)$.

\section{Abbreviations}

ANE: Ascophyllum nodosum extract; PAL: Phenylalanine ammonia lyases; PDI: Percent disease severity; PO: Peroxidase; PPO: Poly phenol oxidase; qRTPCR: Quantitative real-time polymerase chain reaction; RT: Reverse transcriptase; SD: Standard deviation; TPC: Total phenolic content

\section{Acknowledgements}

We are thankful to Dr. Tudor Borza for editing the manuscript.

\section{Authors' contributions}

All authors have read and approved the manuscript. JSP and LRG conducted the experiments, JSP and BP wrote the manuscript, PKR and VS helped during the experiment, BP and VS edited the language of the manuscript. All authors read and approved the final manuscript.

\section{Funding}

BP laboratory is funded by a Mitacs, Canada (www.mitacs.ca) and Acadian Seaplants Limited (www.acadian.ca). Funding partners did not play any role in the design of the experiments, data collection and analysis and writing the manuscript.

Availability of data and materials

All gene sequences are available through NCBI database. 


\section{Ethics approval and consent to participate}

Not applicable.

\section{Consent for publication}

Not applicable.

\section{Competing interests}

The authors declare that they have no competing interests.

Received: 23 September 2019 Accepted: 12 February 2020

Published online: 12 March 2020

\section{References}

1. Gritton ET, Ebert RD. Interaction of planting date and powdery mildew on pea plant performance. J American Society Hort Sci. 1975;100:137-42.

2. Warkentin TD, Rashid KY, Xue AG. Fungicidal control of powdery mildew in field pea. Can J Plant Sci. 1996;76:933-5

3. Fondevilla S, Cubero Jl, Rubiales D. Confirmation that the Er3 gene, conferring resistance to Erysiphe pisi in pea, is a different gene from er 1 and er2 genes. Plant Breed. 2011;130:281-2.

4. Liu J. Occurrence and Diversity of Peronospora viciae f. sp. pisi. (Thesis) Master of Science. Canada: University of Alberta; 2011.

5. Tiwari KR, Penner GA, Warkentin TD, Rashid KY. Pathogenic variation in Erysiphe pisi, the causal organism of powdery mildew of pea. Can J Plant Pathol. 1997:19(3):267-71.

6. Falloon R, Sutherland PW, Falloon RE, Hallett IC. Morphology of Erysiphe pisi on leaves of Pisum sativum. Can J Bot. 2013:67:3410-6.

7. Moreira R, Sineiro J, Chenlo F, Arufe S, Díaz-Varela D. Aqueous extracts of Ascophyllum nodosum obtained by ultrasound-assisted extraction: effects of drying temperature of seaweed on the properties of extracts. J Appl Phycol. 2017;29:3191-200

8. Khan W, Rayirath UP, Subramanian S, et al. Seaweed extracts as biostimulants of plant growth and development. J Plant Growth Regul. 2009:28:386-99.

9. Craigie JS. Seaweed extract stimuli in plant science and agriculture. J Appl Phycol. 2011:23:371-93.

10. Mukherjee A, Patel JS. Seaweed extract: biostimulator of plant defense and plant productivity. Int J Environ Sci Technol. 2019:1-6.

11. Jithesh MN, Shukla PS, Kant P, Joshi J. Physiological and transcriptomics analyses reveal that Ascophyllum nodosum extracts induce salinity tolerance in Arabidopsis by regulating the expression of stress responsive genes. J Plant Growth Regul. 2019;38(2):463-78.

12. Jayaraj J, Wan A, Rahman M, Punja ZK. Seaweed extract reduces foliar fungal diseases on carrot. Crop Prot. 2008;27(10):1360-6.

13. Jayaraman J, Norrie J, Punja ZK. Commercial extract from the brown seaweed Ascophyllum nodosum reduces fungal diseases in greenhouse cucumber. J Appl Phycol. 2011:23:353-61.

14. Peres JCF, Carvalho LRD, Gonçalez E, Berian LOS, Felicio JD. Evaluation of antifungal activity of seaweed extracts. Ciência e Agrotecnol. 2012;36(3): 294-9.

15. Lizzi Y, Coulomb C, Polian C, Coulomb PJ, Coulomb PO. Seaweed and mildew: what does the future hold?. Phytoma La Defense des Vegetaux (France); 1998. p. 29-30.

16. Garcia-Mina JM, Antolin MC, Sanchez-Diaz M. Metal-humic complexes and plant micronutrient uptake: a study based on different plant species cultivated in diverse soil types. Plant Soil. 2004;258(1):57-68.

17. Crouch IJ, van Staden J. Evidence for the presence of plant growth regulators in commercial seaweed products. Plant Growth Regul. 1993;13: $21-9$

18. Reitz SR, Trumble JT. Effects of cytokinin-containing seaweed extract on Phaseolus lunatus L.: influence of nutrient availability and apex removal. Bot Mar. 1996;39(1-6):33-8.

19. Lane CE, Mayes C, Druehl LD, Saunders GW. a multi-gene molecular investigation of the kelp (laminariales, phaeophyceae) supports substantial taxonomic re-organization. J Phycol. 2006:42:495-512.

20. El Hadrami A, Adam LR, El Hadrami I, Daayf F. Chitosan in plant protection Marine Drugs. 2010:8:968-87.

21. Romanazzi G, Feliziani E, Sivakumar D. Chitosan, a biopolymer with triple action on postharvest decay of fruit and vegetables: eliciting, antimicrobial and film-forming properties. Front Microbiol. 2018;9:2745.
22. El Hassni M, El Hadrami A, Daayf F, Barka EA, El Hadrami I. Chitosan, antifungal product against Fusarium oxysporum f. sp. albedinis and elicitor of defense reactions in date palm roots. Phytopathol Mediterr. 2004;43:195204.

23. Faoro $F$, Dario $A E, A e M$, et al. Chemical-induced resistance against powdery mildew in barley: the effects of chitosan and benzothiadiazole. Biocontrol. 2008;53:387-401.

24. Moret A, Muñoz Z, Garcés S. Control of powdery mildew on cucumber cotyledons by chitosan. J Plant Pathol. 2009;91(2):375-80.

25. Iriti M, Vitalini S, Tommaso GD, Dmico S, Borgo M, Faoro F. New chitosan formulation prevents grapevine powdery mildew infection and improves polyphenol content and free radical scavenging activity of grape and wine. Australian J Grape Wine Res. 2011:17(2):263-9.

26. Soliman MH, El-Mohamedy RS. Induction of defense-related physiological and antioxidant enzyme response against powdery mildew disease in okra (Abelmoschus esculentus L.) plant by using chitosan and potassium salts. Mycobiol. 2017:45(4):409-20.

27. Subramanian S, Sangha JS, Gray BA, Singh RP, Hiltz D, Critchley AT, Prithiviraj B. Extracts of the marine brown macroalga, Ascophyllum nodosum, induce jasmonic acid dependent systemic resistance in Arabidopsis thaliana against Pseudomonas syringae pv. Tomato DC3000 and Sclerotinia sclerotiorum. Eur J Plant Pathol. 2011;131(2):237-48.

28. Jia R, Duan $Y$, Fang $Q$, Wang $X$, Huang J. Pyridine-grafted chitosan derivative as an antifungal agent. Food Chem. 2016;196:381-7.

29. Patier $P$, Yvin JC, Kloareg B, Liénart Y, Rochas C. Seaweed liquid fertilizer from Ascophyllum nodosum contains elicitors of plant d-glycanases. J Appl Phycol. 1993;5(3):343-9.

30. Kim SW, Park JK, Lee CH, Hahn BS, Koo JC. Comparison of the antimicrobial properties of chitosan oligosaccharides (COS) and EDTA against Fusarium fujikuroi causing rice bakanae disease. Curr Microbiol. 2016;72(4):496-502.

31. Zhou Y, Zhang L, Zeng K. Efficacy of Pichia membranaefaciens combined with chitosan against Colletotrichum gloeosporioides in citrus fruits and possible modes of action. Biol Control. 2016;96:39-47.

32. Dixon RA, Harrison MJ, Lamb CJ. Early events in the activation of plant defense responses. Annu Rev Phytopathol. 1994;32(1):479-501.

33. Farmer EE, Ryan CA. Octadecanoid precursors of jasmonic acid activate the synthesis of wound-inducible proteinase inhibitors. Plant Cell. 1992;4(2):129_ 34.

34. Xing K, Chen XG, Kong M, Liu CS, Cha DS, Park HJ. Effect of oleoyl-chitosan nanoparticles as a novel antibacterial dispersion system on viability, membrane permeability and cell morphology of Escherichia coli and Staphylococcus aureus. Carbohydr Polym. 2009;76(1):17-22.

35. Rakwal R, Tamogami S, Agrawal GK, Iwahashi H. Octadecanoid signaling component "burst" in rice (Oryza sativa L.) seedling leaves upon wounding by cut and treatment with fungal elicitor chitosan. Biochem Biophys Res Commun. 2002;295(5):1041-5.

36. Doares SH, Syrovets T, Weiler EW, Ryan CA. Oligogalacturonides and chitosan activate plant defensive genes through the octadecanoid pathway. PNAS. 1995:92(10):4095-8.

37. Yin H, Li Y, Zhang HY, Wang WX, Lu H, et al. Chitosan oligosaccharidestriggered innate immunity contributes to oilseed rape resistance against Sclerotinia Sclerotiorum. Int J Plant Sci. 2013;174(4):722-32.

38. Obara N, Hasegawa M, Kodama O. Induced volatiles in elicitor-treated and rice blast fungus-inoculated rice leaves. Biosci Biotechnol Biochem. 2002; 66(12):2549-59.

39. Kunkel BN, Brooks DM. Cross talk between signaling pathways in pathogen defense. Curr Opin Plant Biol. 2002:4:325-31.

40. Shah J, Kachroo P, Klessig DF. The Arabidopsis ssi1 mutation restores pathogenesis-related gene expression in npr1 plants and renders defensin gene expression salicylic acid dependent. Plant Cell. 1999;11(2):191-206.

41. Patel JS, Kharwar RN, Singh HB, Upadhyay RS, Sarma BK. Trichoderma asperellum (T42) and Pseudomonas fluorescens (OKC)-enhances resistance of pea against Erysiphe pisi through enhanced ros generation and lignifications. Front Microbiol. 2017;08:306.

42. Julliany K, Silva P, Mahna N, Mou Z, Folta KM. NPR1 as a transgenic crop protection strategy in horticultural species. Hort Res. 2018;5:15.

43. Macpherson N, Takeda S, Shang Z, Dark A, et al. NADPH oxidase involvement in cellular integrity. Planta. 2008:227(6):1415-8.

44. Shukla PS, Borza T, Critchley AT, Hiltz D, Norrie J, Prithiviraj B. Ascophyllum nodosum extract mitigates salinity stress in Arabidopsis thaliana by 
modulating the expression of miRNA involved in stress tolerance and nutrient acquisition. PLoS One. 2018;13(10):e0206221.

45. Singh UP, Sarma BK, Singh DP, Bahadur A. Plant growth-promoting rhizobacteria-mediated induction of phenolics in pea (Pisum sativum) after infection with Erysiphe pisi. Curr Microbiol. 2002;44:396-400.

46. Fondevilla S, Carver TLW, Moreno MT, Rubiales D. Identification and characterization of sources of resistance to Erysiphe pisi Syd. In Pisum spp. Plant Breed. 2007;126:113-9.

47. Havir EA. L-phenylalanine Ammonia-Lyase from soybean cell suspension cultures. Methods Enzymol. 1987;142:248-53.

48. Bergmeyer $\mathrm{H}$, Bernt E. Determination of glucose with glucose oxidase and peroxidase. Methods Enzym Anal. 1974;2:1205-15.

49. Velikova V, Yordanov I, Edreva A. Oxidative stress and some antioxidant systems in acid rain-treated bean plants. Plant Sci. 2002;151:59-66.

50. Graham HD. Stabilization of the Prussian blue color in the determination of polyphenols. J Agric Food Chem. 1992;40:801-5.

51. Singleton VL, Rossi JA. Colorimetry of total phenolics with P-molybdic tungstic acid reagents. Am J Enol Vitic. 1965;16:144-58.

52. Patel JS, Sarma BK. Designing and experimental evaluation of gene-specific primers of pea (Pisum sativum) defense proteins. 3. Biotech. 2018;8:482.

53. Marone M, Mozzetti S, De Ritis D, Pierelli L, Scambia G. Semiquantitative RTPCR analysis to assess the expression levels of multiple transcripts from the same sample. Biol Proced Online. 2001;3(1):19.

54. Schmittgen TD, Livak KJ. Analyzing real-time PCR data by the comparative CTmethod. Nat Protoc. 2008;3:1101-8.

\section{Publisher's Note}

Springer Nature remains neutral with regard to jurisdictional claims in published maps and institutional affiliations.

Ready to submit your research? Choose BMC and benefit from:

- fast, convenient online submission

- thorough peer review by experienced researchers in your field

- rapid publication on acceptance

- support for research data, including large and complex data types

- gold Open Access which fosters wider collaboration and increased citations

- maximum visibility for your research: over $100 \mathrm{M}$ website views per year

At $\mathrm{BMC}$, research is always in progress.

Learn more biomedcentral.com/submissions 